\begin{tabular}{l} 
RCCS \\
\hline Annual Review
\end{tabular}

\section{RCCS Annual Review}

A selection from the Portuguese journal Revista Crítica de Ciências Sociais

$1 \mid 2009$

Issue no. 1

\title{
Knowledge of Africa, Knowledge by Africans: Two Perspectives on African Studies
}

\section{Paulin J. Hountondji}

\section{OpenEdition \\ Journals}

Electronic version

URL: https://journals.openedition.org/rccsar/174

DOI: $10.4000 /$ rccsar. 174

ISSN: 1647-3175

\section{Publisher}

Centro de Estudos Sociais da Universidade de Coimbra

\section{ELECTRONIC REFERENCE}

Paulin J. Hountondji, “Knowledge of Africa, Knowledge by Africans: Two

Perspectives on African Studies", RCCS Annual Review [Online], 1 | 2009, Online since 01 septembre 2009, connection on 28 juin 2022. URL: http://journals.openedition.org/ rccsar/174 ; DOI: https://doi.org/10.4000/rccsar.174

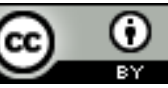

RCCS Annual Review is licensed under a Creative Commons Attribution 4.0 International License. 
Paulin J. Hountondji

National University of Benin

African Centre for Advanced Studies, Benin

\section{Knowledge of Africa, Knowledge by Africans: Two Perspectives on African Studies*}

How African are the so-called African Studies? The study of Africa, as developed so far by a long intellectual tradition, is part of an overall project of knowledge accumulation initiated and controlled by the West. This article advocates an active, lucid, responsible appropriation by African societies themselves of the knowledge capitalised over centuries about them. It advocates more generally the development in Africa of an autonomous, self-reliant tradition of research and knowledge that addresses problems and issues directly or indirectly posed by Africans. It calls upon "épistémologies du Sud." It calls upon African scholars in African Studies and in all other disciplines to understand that they have been doing so far a kind of research that was massively extraverted, i. e. externally oriented, intended first and foremost to meet the theoretical and practical needs of Northern societies. It invites a new orientation and new ambitions for research by Africans in Africa.

Keywords: African Studies; research; knowledge; Southern epistemologies.

1. By African Studies we usually mean not just one discipline but the whole range of disciplines that take Africa as a subject of study. Among other such disciplines are often mentioned "African history," "African sociology and anthropology," "African linguistics," "African politics," "African philosophy," etc. A first question therefore becomes unavoidable: is there any kind of unity between these disciplines? Do they just relate to Africa each on its own without being anyhow interrelated? Are they simply juxtaposed to one another while studying the same object from different angles and perspectives, or are they instead interdependent in such a way that they are bound to grow or fade together? One easily perceives the implication: if these disciplines do not need one another, if each of them can flourish by its own without drawing on any neighbouring discipline, then there is no need to put them together in the same institution, no need to create institutes of African Studies, let alone something as big as BIG-SAS is expected to be.

We assume actually that these disciplines are somehow interrelated and we have good reasons to do so. Between African history and African sociology, for instance, there is

\footnotetext{
* Article originally published in RCCS 80 (March 2008). It is a revised version of a lecture delivered during the opening ceremony of the Bayreuth International Graduate School of African Studies (BIGSAS), University of Bayreuth, Germany, on December 13, 2007. I am grateful to the Alexander von Humboldt Foundation for giving me the possibility to have another three months research stay in Germany during that period. My first Humboldt fellowship dates back to the years 1980-1982. I was hosted by the Philosophy Institute of the University of Düsseldorf, then directed by the late Professor Alwin Diemer.
} 
obviously an objective complementarity inasmuch as the present situation of any society derives directly or indirectly from its past. On the other hand, a good knowledge of the present and of the logic of events in today's life may give useful insights into the comprehension of the past. Synchrony therefore refers to diachrony and vice-versa. History and sociology are just an example. Similar relations can be found between all the disciplines that constitute African Studies.

There is more, however. Beyond the special links that unite disciplines studying the same object, there is an overall solidarity between the sciences both intellectually and historically. Not only do the so-called African Studies rely on methodologies and theories which consolidated in various fields, like general history, sociology, linguistics, economics, political science, etc., long before they were applied to Africa as a new field of study, but moreover, as everybody can see, BIG-SAS is part of the Institute of African Studies, which itself is part of the University of Bayreuth, i.e. an institution where many other disciplines, including mathematics, physics, computer science, biology, chemistry, geology, business and administration, philosophy, engineering, are taught and researched in, in addition to African Studies and to the mother disciplines of African Studies themselves. And it is the same everywhere. This institutional setting is not peculiar to Bayreuth. It clearly indicates how deeply the different areas of research are interconnected. Such interconnection, as is well known, is at the root of the very idea of university (Universitas) as was thematised among others by a man who was not only a thinker but also the real founder of the Wissenschaftspolitik in $19^{\text {th }}$ century Germany: Wilhelm von Humboldt.

2. There is at least one more question: how African are the so-called African Studies? By African history, for instance, we usually mean the historical discourse on or about Africa and not necessarily a historical discourse coming from Africa or produced by Africans. In grammatical terms we mean the history of Africa: historia Africae in Latin, where Africae, the genitive of Africa, would be said to be an objective genitive rather than a subjective genitive. In the same line, African sociology or anthropology means the sociology or anthropology of Africa as an objective genitive, that is a sociological or anthropological discourse on Africa and not a sociological or anthropological tradition developed by Africans within Africa. Similarly, African linguistics is understood as the study of African languages and not necessarily a study by Africans. Imagine a group of African scholars studying 
Japanese, for instance, or English, German or Portuguese. They would not be said to be contributing to the development of a linguistic research tradition in Africa. Instead they would be said to be doing Japanese linguistics, English, German or Portuguese linguistics.

In my own intellectual development I was sensitised to this problem and started perceiving it as a problem while reading books on "African philosophy" or African systems of thought. The authors usually assumed that Africans themselves were not conscious of their own philosophy, and that only Western analysts observing them from without could give a systematic account of their wisdom. Father Placide Tempels, a Belgian missionary working in the former Belgian Congo, must be credited for giving the most explicit formulation of this assumption:

Let us not expect the first Black-in-the-street (especially if he is young) to give us a systematic account of his ontological system. Nevertheless this ontology exists; it penetrates and informs all the primitive's thinking and dominates all his behaviour. Using the methods of analysis and synthesis of our own intellectual disciplines, we can and therefore must do the 'primitive' the service of looking for, classifying and systematizing the elements of his ontological system. (Tempels, 1969: 15)

And further on:

We do not claim that the Bantus are capable of presenting us with a philosophical treatise complete with an adequate vocabulary. It is our own intellectual training that enables us to effect its systematic development. It is up to us to provide them with an accurate account of their conception of entities, in such a way that they will recognize themselves in our words and will agree, saying: "You have understood us, you know us now completely, you 'know' in the same way we 'know'. (Tempels, 1969: 24)

What is wrong about this alleged unawareness of the natives about their own philosophy is that the latter is said to be the most self-conscious discipline, at least in a certain philosophical tradition, precisely the one in which I had been brought up myself: the philosophy of consciousness as developed from Plato to Descartes, Kant and Husserl, to mention just a few important landmarks in this tradition.

What bothered me most was the fact that an increasing number of African intellectuals were stepping in the same direction. African academics doing philosophy in or outside Western universities spent most of their time writing M.A. theses, Ph.D. dissertations, articles, books, conference papers or monographs of all sorts on such topics as the philosophy of being among the people of Rwanda, the concept of time among the people of 
East Africa, the perception of the old man among the Fulas of Guinea, the Yoruba conception of human being, Yoruba metaphysical thinking, moral philosophy among the Wolof, the Akan doctrine of God, the conception of life among the Fon of Dahomey, etc. I found these topics interesting per se and some of the monographs particularly insightful. But I could not admit that the first duty, let alone the only duty of African philosophers, was to describe or reconstruct the worldview of their ancestors or the collective assumptions of their communities. I contended therefore that most of these scholars were not really doing philosophy but ethno-philosophy: they were writing a special chapter of ethnology aimed at studying the systems of thought of those societies usually studied by ethnology ${ }^{1}-$ however such societies are defined or characterised. ${ }^{2}$

At the same time, however, I drew attention to the very existence of these monographs. To me they were part and parcel of African philosophy in a radically new sense. In my view African philosophy should not be conceived as an implicit worldview unconsciously shared by all Africans. African philosophy was quite simply philosophy done by Africans. There was a contradiction in Western philosophy while thinking of itself as the most self-conscious of all intellectual disciplines and at the same time assuming that some non-Western philosophies could be self-unconscious.

I drew attention, therefore, to the existence of an African philosophical literature. The very first sentence of my little book, African Philosophy, Myth and Reality, made this

\footnotetext{
${ }^{1}$ As is well known, the word "ethno-philosophy" was used in the early seventies almost at the same time by my colleague Marcien Towa from Cameroon and myself in a derogatory and polemical sense (Hountondji, 1970; Towa, 1971). But the word itself was older. It dates back at least to the early forties when Nkrumah used it in a quite positive sense to describe a discipline to which he himself wanted to contribute. As mentioned in his autobiography, Nkrumah got his M.A. in philosophy in 1943 at the University of Pennsylvania, Philadelphia, and registered soon after for a Ph.D. in "ethno-philosophy." He actually wrote the thesis but could not defend it before leaving in 1945 to Britain, where he served as secretary to the fifth Pan-African Congress. I am indebted to William Abraham for providing me with a copy of the typewritten manuscript. The word "ethno-philosophy" already appears in the title: Mind and Thought in Primitive Society: a Study in Ethno-Philosophy with Special Reference to the Akan Peoples of the Gold Coast, West Africa (Nkrumah, 1945; 1957).

${ }^{2}$ There is a broad consensus today that notions traditionally used to identify the kind of societies studied by ethnology (as opposed to sociology) are strongly Eurocentric and in this sense biased or "ideological." Scholars are at pains to explain exactly what they mean by "primitive" societies. Alternative notions supposed to be more politically correct, such as "archaic" societies, "traditional" societies, "indigenous" peoples, etc., are not much clearer. Describing ethnology as the study of "illiterate" societies is not better either, insofar as the societies concerned are thus characterised negatively by something which they don't have: literacy. It is more productive to pay attention to the specific ways and devices through which knowledge is transmitted without using writing in the way it is used in the West. For this reason they should be called, as suggested by the French linguist Maurice Houis, civilisations de l'oralité - oral civilisations. Mamoussé Diagne, a philosopher from Senegal, has carefully analysed in his Critique of Oral Reason this "logic of orality," as opposed to the logic of writing described by Jack Goody, and the impact of this specific way of transmission on the knowledge produced (Houis, 1971; Goody, 1986; Diagne, 2005).
} 
statement which may appear retrospectively today as a "vérité de La Palice," a commonplace idea, something quite simple indeed, which, however, due to the intellectual and ideological landscape of the time, seemed extraordinarily new: "By African philosophy I mean a set of texts" (Hountondji, 1977, 1983). If this book has made such a strong impression, to the extent of being awarded the Herskovits prize in Los Angeles in 1984 and being more recently selected in 2002 at the Zimbabwe International Book Fair in Harare among the hundred best African books of the $20^{\text {th }}$ century, it must be due to this simple and apparently naive statement whose implications and consequences, however, were farreaching.

One immediate implication was this: the new concept of African philosophy allowed a distinction between Africanists and Africans in the field of philosophy. Many Western thinkers who wrote extensively on African systems of thought could no longer be viewed as belonging to African philosophy in the new sense, while the works by their African counterparts were part of the African writings in ethno-philosophy and therefore were part and parcel of the African philosophical literature. This does not mean that the works by Africans were better in any sense of the word. Besides, nobody can ignore the thematic solidarity or even the intellectual complicity between African and non-African ethnophilosophy, nor deny the genealogic filiation that makes African ethno-philosophy the daughter of Western engagement with exotic worldviews. Drawing this kind of demarcation, however, made it possible to call attention to the African reception of Western research traditions and get African scholars to face their own intellectual responsibility.

There is still another implication: African philosophy also includes writings that criticise or question ethno-philosophy, which clearly indicates that there is no unanimity whatsoever within Africa on this specific issue. Equating African philosophy with African philosophical literature made it possible to perceive the internal debates and contradictions, the intellectual tensions that make this philosophy a vivid one, and African culture as a whole a living, not a dead culture. Ethno-philosophy was based, among other assumptions, on the idea that, in small-scale societies or so-called primitive societies, there was total unanimity and, so to say, everyone agrees with everyone. Moreover, this alleged unanimity was viewed as a virtue, and dissent as something bad or dangerous. I called this double assumption the unanimist illusion. I drew attention instead to the virtue of pluralism as a factor of progress and to the fact that not only modern Africa but even the so-called traditional Africa have 
been experiencing pluralism over time in all domains. As far as philosophy is concerned, this kind of pluralism appeared to me as something most valuable and fruitful (Hountondji, 2002).

Needless to say, African philosophy extends to a whole range of works that have nothing or very little to do with the specific issue of the existence of African philosophy, and therefore cannot just be classified along the line Ethno-philosophy vs. Critical Philosophy. Some writings develop African attempts to think, rethink or simply understand Western philosophy and appropriate, so to say, non-African traditions of thought. They give birth to African interpretations of Descartes, Kant, Hegel, Marx, Husserl, the Critical School of Frankfurt, Islamic thinkers, maybe tomorrow Indian and Chinese philosophies, and many other intellectual traditions from outside Africa. Some others work on universal issues and concepts, including issues on mathematical logic or the foundations of science, the history and sociology of science, the anthropology of knowledge, ethics and political philosophy, philosophy of language, etc. Such attempts, of course, are part and parcel of African philosophy.

3. Now, how does all this apply to African Studies? In a sense, the study of Africa is stamped with a kind of original sin in view of the objective role it played in the history of colonisation. In the case of Germany the problem is even more serious, given the way the discipline was instrumentalised during the period of national-socialism.

This, however, is part of history. The historical complicity has been denounced again and again not only by non-Western scholars but also, and this is more important, by Western scholars themselves. Moreover, as far as the Hitlerian period is concerned, there must have been at the very height of this awful dictatorship at least some shy protests which could not be loudly articulated unless one wanted to commit suicide. I would assume, as was written recently by a German anthropologist, that, "despite prominent examples, it would be misleading [...] to see all members of African studies as playing an active role in Hitler's Germany. The appropriate picture was rather, as Dostal has called it, silence in darkness" (Probst, 2005; Dostal, 1994).

Despite this original sin, therefore, Western scholarship including German Afrikanistik has made a huge contribution to the knowledge of African languages, societies, history and cultures. Some names remain unforgettable, such as Adolf Bastian, the "father of the 
German Völkerkunde," to use the words of an African anthropologist; ${ }^{3}$ Carl Meinhof, the specialist of Bantu languages; Diedrich Westermann, who was missionary in Togo before starting his brilliant career as an anthropologist; Leo Frobenius, whose work contributed a lot to giving Black writers like Aimé Césaire and Léopold Sedar Senghor better awareness of the fundamentals and value of their own culture; Janheinz Jahn, who was so strongly impressed while listening to a lecture by Senghor in 1951 that he started almost immediately "his untiring collection and translation of African literature" (Probst, 2005: 415); and nearer to us a man like Ulli Beier, who founded in Bayreuth the institution called in German "Ivaleva Haus" (because the sound "w" like "window" in English does not exist in German), where the Yoruba pronounces "Iwa lewa" - "beauty is character," e.g., "the beautiful woman is the one who behaves well." We cannot forget the late Georg Elwert, to whom the peasants of Ayou, the village in Benin where he did most of his fieldwork, paid a vibrant homage in October $2006 .^{4}$

As an external observer I would probably not describe, as Peter Probst does (2005: 405), African Studies in Germany as being "betwixt and between [...] two major spheres of influence," the French and the British ones - assise entre deux chaises, as would be said in French: sitting between two chairs without its own identity. Instead, the German tradition seems to me the model of what we should try to build in Africa. First, it speaks its own language, German. Second, by way of implication, it addresses primarily a German-speaking audience and evolves first and foremost as an internal debate within Germany and Germanspeaking countries, including Austria and part of Switzerland, where scholars question one another, respond to and discuss with one another. Third, the debated issues are significant for, and largely shared by, the German-speaking academic community - which allows the development of a horizontal and self-sustained debate. We are not in a situation where the individual scholar shares in a problematic developed elsewhere, say, in the French or the English-speaking world, over the shoulder of his/her own community. Fourth, debating

\footnotetext{
${ }^{3}$ See Diallo, 2001.

${ }^{4}$ The villagers were invited to attend a two-hour session in "homage to Georg Elwert, a German Africanist (1947-2005)" during an international conference organised in Cotonou from October 16 to 19, 2006 by the African Centre for Advanced Studies. Instead of one or two delegates, they brought in a big delegation of 25 people with drums and other sophisticated instruments. They explained in Aizo (a variant of Fongbe) what that man meant to them, recalling, among other things, how he taught them to write and read their own language, how he helped them to find out funds to sink wells and get drinking water in their villages. With permission of their elders, they executed sacred dances that could only be danced in special circumstances. This amounted, in fact, to organising a second burial ceremony.
} 
endogenous issues does not amount to scientific autarky or intellectual self-imprisonment. Not only do some scholars publish part of their work in French or more often in English, the new lingua franca of international scholarship, in order to reach a wider audience, but it can be assumed that whenever a discussion originally launched in Germany becomes significant for the international scientific community, non-German scholars themselves feel the need to have it translated as soon as possible.

This way of doing research can be said to promote an autonomous, self-reliant scientific activity. Instead, I am afraid the way we do research in Africa is just the opposite. Too often do we tend to investigate subjects which are of interest first and foremost to a Western audience. Most of our articles are published in journals located outside Africa and are meant therefore for a non-African readership. Even when we happen to publish in Africa, the fact is that African scholarly journals themselves are read much more outside Africa than in Africa. In this sense, our scientific activity is extraverted, i.e. externally oriented, intended to meet the theoretical needs of our Western counterparts and answer the questions they pose. The exclusive use of European languages as a means of scientific expression reinforces this alienation. The majority of our country people are de facto excluded from any kind of discussion about our research outcome, given that they don't even understand the languages used. The small minority who understands knows, however, that they are not the first addressees but only, if anything, occasional witnesses of a scientific discourse meant primarily for others. To put it bluntly, each African scholar has been participating so far in a vertical discussion with his/her counterparts from the North rather than developing horizontal discussions with other African scholars (see Taiwo, 1993, Hountondji, 1988a; 1990; 1995; 2006).

Am I going too far? No doubt this description would have been quite adequate fifty years ago or so. But things have changed ever since. We do have today in Africa, in the various fields of academia, national, sub-regional, regional scientific communities. We have universities and research centres and some of them are very good. We have brilliant scientists and scholars, and some of them are doing quite well. Despite all this progress, however, we are still a long way behind what should be perceived as our final goal: an autonomous, self-reliant process of knowledge production and capitalisation that enables us to answer our own questions and meet both the intellectual and the material needs of African societies. The first step in this direction would probably be to formulate original 
"problematics," original sets of problems that are grounded in a solid appropriation of the international intellectual legacy and deeply rooted in the African experience (Hountondji, 1988b; 1997; 2002).

In this perspective, the discipline or set of disciplines called African Studies will certainly not have the same meaning in Africa as in the West. In Africa it is or should be part of a wider project: knowing oneself in order to transform. African Studies in Africa should not be satisfied with just contributing to the accumulation of knowledge about Africa, a kind of knowledge that is capitalised in and managed by the North as all other sectors of scientific knowledge. African scholars involved in African Studies should have another priority, which is to develop first and foremost an Africa-based tradition of knowledge in all disciplines, a tradition where questions are initiated and research agendas set out directly or indirectly by African societies themselves. Non-African scholars will then be expected to contribute to solving these questions and implementing these research agendas from their own perspective and historical background.

Things should also happen in Africa, therefore, and not always or exclusively outside Africa. Fairness to the Black continent demands that all the knowledge accumulated throughout centuries on different aspects of its life be shared with the people who live there. It demands that adequate measures be taken to facilitate a lucid, responsible appropriation by Africa of the knowledge available, the discussions and interrogations developed elsewhere. Such appropriation should go hand in hand with a critical reappropriation of Africa's own endogenous knowledges and, beyond, a critical appropriation of the very process of knowledge production and capitalisation. ${ }^{5}$

\footnotetext{
${ }^{5}$ It has been shown in a convincing manner how deeply the study of Africa has impacted on the mother disciplines in the social sciences and humanities (Bates, Mudimbe \& O'Barr, 1993). While acknowledging this important fact, the point I am trying to make here is slightly different. Both these core disciplines and African Studies have been so far developing mostly in the West. But Africa should now develop its own process of questioning and accumulating knowledge, not only in the field of African Studies, but in all academic disciplines. In this sense it should be noted that "Research in Africa," as mentioned in the subtitle of the book, does not mean research within Africa, but just research about Africa or research in African Studies. The point here is that Africa should not be reduced to a subject of study. Geography matters. The more things are done in Africa the better for the present and future of this continent.
} 


\section{References}

Bates, Robert H.; V. Y. Mudimbe; Jean O'Barr (eds.) (1993), Africa and the Disciplines: The Contributions of Research in Africa to the Social Sciences and Humanities. Chicago: University of Chicago Press.

Diagne, Mamoussé (2005), Critique de la raison orale: les pratiques discursives en Afrique noire. Niamey/ Paris/ Dakar: CELHTO/ Karthala/ IFAN.

Diallo, Youssouf (2001), "L'africanisme en Allemagne hier et aujourd'hui," Cahiers d'études africaines, 161: 13-43.

Dostal, Walter (1994), "Silence in the Darkness: German Ethnology during the National Socialist Period," Social Anthropology: Journal of the European Association of Social Anthropologists, 2 (3): 251-262.

Goody, Jack (1986), The Logic of Writing and the Organization of Society. Cambridge: Cambridge University Press.

Houis, Maurice (1971), Anthropologie linguistique de l'Afrique noire. Paris: PUF.

Hountondji, Paulin (1970), "Remarques sur la philosophie africaine contemporaine," Diogène, 71: 120-140.

Hountondji, Paulin (1977), Sur la "philosophie africaine". Critique de l'ethnophilosophie. Paris: François Maspero.

Hountondji, Paulin (1983), African Philosophy: Myth and Reality. Bloomington: Indiana University Press

Hountondji, Paulin (1988a), "Situation de l'anthropologue africain: note critique sur une forme d'extraversion scientifique," in Gabriel Gosselin (ed.), Les nouveaux enjeux de l'anthropologie. Autour de Georges Balandier, special issue of Revue de l'Institut de sociologie (Bruxelles), 3-4: 99-108.

Hountondji, Paulin (1988b), "L'appropriation collective du savoir: tâches nouvelles pour une politique scientifique, " Genève-Afrique, 26 (1): 49-61.

Hountondji, Paulin (1990) "Scientific Dependence in Africa Today," Research in African Literatures, 21 (3): 5-15.

Hountondji, Paulin (1995), "Producing Knowledge in Africa Today," African Studies Review, 38 (3): 1-10.

Hountondji, Paulin (ed.) (1997), Endogenous Knowledge: Research Trails. Dakar: CODESRIA.

Hountondji, Paulin (2002), The Struggle for Meaning: Reflections on Philosophy, Culture, and Democracy in Africa. Athens: Ohio University Center for International Studies.

Hountondji, Paulin (2006), "Global Knowledge: Imbalances and Current Tasks," in Guy Neave (ed.), Knowledge, Power and Dissent: Critical Perspectives on Higher Education and Research in Knowledge Society. Paris: Unesco Publishing: 41 - 60

Hountondji, Paulin (ed.) (2007), La Rationalité, une ou plurielle? Dakar: CODESRIA.

Nkrumah, Francis K. (n.d., n.p., circa 1945), Mind and Thought in Primitive Society. A Study in Ethno-Philosophy with Special Reference to the Akan Peoples of the Gold Coast, West Africa (Typewritten). 
Nkrumah, Kwame (1957), Ghana. Autobiography of Kwame Nkrumah. London: Nelson.

Probst, Peter (2005), "Between and Betwixt. African Studies in Germany," Afrika Spectrum, 30 (3): 403-427.

Taiwo, Olufemi (1993), "Colonialism and its Aftermath: The Crisis of Knowledge Production," Callalloo, 16 (3): 891-908.

Tempels, Placide (1969), Bantu Philosophy. Trans. Colin King. Paris: Présence Africaine [1945].

Towa, Marcien (1971), Essai sur la Problématique Philosophique dans l'Afrique actuelle. Yaoundé: CLE. 